\title{
Public Knowledge and Attitudes Regarding Antibiotic Use in Ankara, Turkey
}

\author{
Alpay Azap², Tuğrul Orhan Akın², Miray Başçavuş², Elçin Ercan², Devrim Deniz Kuşçu², İrem Namal², Mehmet Yılmaz² \\ 1 Department of Infectious Diseases and Clinical Microbiology, Ankara University School of Medicine, Ankara, Turkey \\ 2 Ankara University School of Medicine, Ankara, Turkey
}

\begin{abstract}
Objective: Turkey is one of the countries with the highest antibiotic consumption per capita and suffers widespread antimicrobial resistance. However, few studies are measuring the knowledge, attitude and behaviour regarding antibiotic use in Turkey. We aimed to describe the awareness, knowledge, beliefs, attitude and behaviour of the society regarding antibiotic use and antimicrobial resistance.

Materials and Methods: The study was carried out at a large shopping mall with 60 000-75 000 visitors daily in the capital city of Turkey, Ankara. We applied a questionnaire to the visitors who accepted to participate for two days. The data were collected on demographics, knowledge, attitude and beliefs concerning antibiotic use and awareness of judicious antibiotic use (JAU) and related factors.

Results: Of the 1044 people who attended the study, 554 were male (52.1\%). The average age of the participants was 37.7. JAU was found to be high (10/10 points) in 127 participants (12.2\%). JAU was statistically high among people who were informed about the potential harms of inappropriate antibiotic use by physicians $(p<0.001)$, who had university degree $(\mathrm{p}=0.005)$, who did not used to use antibiotics without prescriptions $(\mathrm{p}<0.001)$, and who did not use antibiotics within the last year $(\mathrm{p}<0.001)$.

Conclusion: Awareness and knowledge about JAU in Ankara were low. There are misbeliefs and inappropriate attitudes in terms of antibiotic use and antimicrobial resistance. Necessary precautions should be taken immediately to improve this issue.
\end{abstract}

Corresponding Author: Alpay Azap

E-mail:

Alpay.Azap@medicine.ankara. edu.tr

Received: November 17, 2019 Accepted: December 4, 2019 Published: December 25, 2019

\section{Suggested citation:}

Azap A, Akın TO, Başçavuş M, Ercan E, Kuşçu DD, Namal i, at al. Public knowledge and attitudes regarding antibiotic use in Ankara, Turkey. Infect Dis Clin Microbiol 2019; 3: 134-142.

DOI: 10.36519/idcm.2019.19025 
Antimicrobial resistance is closely related to inappropriate antibiotic use (1-3). Besides the role of physicians, the knowledge, beliefs and behaviour of patients play a role in inappropriate antibiotic use (4). Studies conducted in different settings have shown that inappropriate behaviours regarding antibiotic use are over 50\% (5). On the other hand, endeavours to raise awareness among physicians and the public can seriously reduce inappropriate antibiotic use (6).

Surveillance studies showed that Turkey is one of the countries with the highest antibiotic consumption per capita and suffers widespread antimicrobial resistance $(7,8)$. Few studies are measuring the knowledge, attitude, and behaviour of the public regarding antibiotic use in Turkey (9). This study is conducted in Ankara to determine public awareness related to judicious antibiotic use (JAU) and antimicrobial resistance.

\section{MATERIALS AND METHODS}

The study was carried out on March 18 and 19, 2017 at a large shopping mall with 60 000-75 000 visitors daily, in the capital city of Turkey, Ankara.

\section{HIGHLIGHTS}

- Turkey is one of the countries with the highest antibiotic consumption per capita and suffers widespread antimicrobial resistance.

- Judicious antibiotic use (JAU) was found to be high in only $12.2 \%$ (127/1044) of the participants.

- $24.3 \%$ of participants demand antibiotics when they visit a physician. Of these, $83.5 \%$ have reported that the physicians complied with their demands.

- $67.5 \%$ of participants were aware of the term of antibiotic resistance while 117 (17.1.\%) of these could not link antibiotic use and the development of resistance.

- The main source from where the participants heard the term of antibiotic resistance was the internet $(\mathrm{n}=348,51.03 \%)$.

- High level of education and being informed about the possible harms of antibiotic use were found to be related to JAU.
Through face-to-face interviews, a questionnaire was applied to 1044 consenting adult (age> 18) participants. The survey consisted of 19 questions: Eight for demographic variables, ten for assessing the knowledge, attitude and behaviour on antibiotic usage, and 1 for awareness of antimicrobial resistance (supplemental material). The participants who correctly answered all 10 questions that measured knowledge, attitude and behaviour were scored high and considered as judicious antibiotic users. The factors affecting JAU were determined on this base.

The data obtained from the questionnaires were recorded on a standard sheet and statistically analyzed by SPSS 11.5. The chi-square test was used for comparisons of categorical variables, and continuous variables were analyzed with the t-test. A logistic regression model was generated with including variables which were found to be significant in univariate analysis. Statistical significance was set as $\mathrm{p}<0.05$.

Permission was obtained from the Ankara University School of Medicine Ethical Committee for the study. All participants were informed, and we obtained their written consents.

\section{RESULTS}

The demographics and independent variables were summarized in table 1.

Among the participants, 127 (12.7\%) people were found to have a JAU score of 10. A monthly income of $>5000$ TL, being a health care worker, the higher level of education and cultural status were related to a high JAU score. Other characteristics of participants affecting JAU were given in table 2 .

The number of participants who used antibiotic at least once in the last year was 665 (63.7\%) while 139 $(13.4 \%)$ used more than three courses of antibiotics (Table 1). People who used more than three courses of antibiotics were tended to use antibiotics without prescription (OR:2.51, 95\%CI:1.74-3.63, p<0.001).

Of the 1044 participants, 203 (19.4\%) indicated that they stopped taking antibiotics when their 
Table 1. The characteristics of participants ( $N=1044)$

\begin{tabular}{|c|c|}
\hline Characteristics & $\mathrm{N}(\%)$ \\
\hline Age, mean (Min-Max) & $37.7(18-72)$ \\
\hline $\begin{array}{l}\text { Sex } \\
\text { Male } \\
\text { Female }\end{array}$ & $\begin{array}{l}544(52.1) \\
500(47.9)\end{array}$ \\
\hline $\begin{array}{l}\text { Occupation } \\
\text { Healthcare worker } \\
\text { Other }\end{array}$ & $\begin{array}{l}56(5.4) \\
988(94.6)\end{array}$ \\
\hline $\begin{array}{l}\text { Education Status } \\
\text { Elementary school } \\
\text { High school } \\
\text { University }\end{array}$ & $\begin{array}{l}85(8.2) \\
335(32.2) \\
620(59.6)\end{array}$ \\
\hline $\begin{array}{l}\text { Monthly income } \\
<5000 \mathrm{TL}\end{array}$ & $715(68.5)$ \\
\hline $\begin{array}{l}\text { People living in the same house } \\
>4\end{array}$ & $77(16.9)$ \\
\hline $\begin{array}{l}\text { Books read per year } \\
\quad>9\end{array}$ & $376(37.4)$ \\
\hline Daily newspaper readers & $872(83.8)$ \\
\hline $\begin{array}{l}\text { Number of antibiotics used within last year } \\
0 \\
1-3 \\
>3\end{array}$ & $\begin{array}{l}379(36.3) \\
525(50.3) \\
139(13.4)\end{array}$ \\
\hline Antibiotic use without prescription & $287(27.6)$ \\
\hline Education about antibiotics* & $169(16.2)$ \\
\hline $\begin{array}{l}\text { Informed by their health care providers } \\
\text { regarding the possible harms of antibiotic } \\
\text { use }\end{array}$ & $363(34.9)$ \\
\hline
\end{tabular}

* Participating in an educational activity about antibiotics (such as taking a lecture, attending a conference, lesson at school).

complaints subsided and not completed the entire course of treatment as recommended by their physicians. A small number of participants ( $\mathrm{n}=98,9.4 \%)$ have stated that they have given their leftover antibiotics to other people. The number of people who used antibiotics without visiting a physician was $280(27.2 . \%)$.

One hundred seventeen (11.5\%) of the participants were thinking that antibiotics had no harmful effects. Possible harmful effects of antibiotics were stated as organ damage $(\mathrm{n}=224,29 \%)$, various health problems such as gastrointestinal disturbances ( $\mathrm{n}=150,19.5 \%)$, and development of antibiotic resistance $(n=135,17.5 \%)$ by the remaining 927 participants.

Two hundred forty-nine (24.3\%) of the participants reported that they demanded a prescription for antibiotic during the visit with their physician. Of those, $208(83.5 \%)$ reported that the physician fulfilled their request. One hundred twelve (10.8\%) of the participants have reported that they are taking antibiotics for fever, 206 (19.7\%) have reported the same for sore throat and 79 (7.5\%) for runny nose. One hundred (9.5\%) participants have reported that they have used antibiotics on the recommendations of their acquaintances with no medical training. One hundred thirty-two (12.7\%) have reported that they have recommended the use of antibiotics to others that they thought were sick.

Six hundred eighty-four (67.5\%) of the participants have reported that they have heard the term of antibiotic resistance. The most common source of this information was the internet for 348 of the participants (51.1\%). Among the people who heard of antibiotic resistance, 117 (17\%) did not know that inappropriate antibiotic usage caused resistance. All health care workers correctly stated that inappropriate antibiotic usage might lead to antimicrobial resistance.

In the multivariate analysis; being informed by physicians about the possible harms of inappropriate antibiotic usage, having a university degree, using antibiotics with prescription only, and no antibiotic use within the last year were found to be significantly related to JAU (Table 2).

\section{DISCUSSION}

Judicious use of antibiotics is defined as using antibiotics only when needed for infections for an appropriate duration, at an appropriate dose, and at the lowest cost possible considering individual characteristics (10). In Turkey, with the most antibiotic usage per capita amongst OECD countries, it is determined that at least 35 out of every 100 prescriptions included an antibiotic (8). Indeed, $63.7 \%$ of our participants have reported using antibiotics 
Table 2. Analysis of the characteristics affecting Judicious Antibiotic Use

\begin{tabular}{|c|c|c|c|c|c|c|c|}
\hline \multirow{2}{*}{ Variable } & \multirow{2}{*}{$\begin{array}{l}\text { Number of subjects } \\
\text { with a JAU score of } \\
10 \mathrm{~N}=127(\%)\end{array}$} & \multicolumn{3}{|c|}{ Univariate Analysis } & \multicolumn{3}{|c|}{ Multivariate Analysis* } \\
\hline & & OR & $\% 95 \mathrm{Cl}$ & $P$ value & OR & $\% 95 \mathrm{Cl}$ & $P$ value \\
\hline Age (average) & 39,4 & 1.52 & $0.55-4.43$ & 0.93 & NA & NA & NA \\
\hline $\begin{array}{l}\text { Sex } \\
\text { Female }\end{array}$ & $70(55,1)$ & 0.87 & $0.60-1.26$ & 0.46 & NA & NA & NA \\
\hline Income $>5000 \mathrm{TL}$ & $53(41.7)$ & 1.66 & $1.13-2.43$ & 0.008 & 1.33 & $\begin{array}{l}0.87- \\
2.02\end{array}$ & 0.177 \\
\hline $\begin{array}{l}\text { Being a healthcare } \\
\text { worker }\end{array}$ & $13(10.2)$ & 2.31 & $1.20-4.44$ & 0.009 & 1.17 & $\begin{array}{l}0.51- \\
2.66\end{array}$ & 0.708 \\
\hline High cultural status & $54(42.5)$ & 1.63 & $1.11-2.38$ & 0.011 & 1.36 & $\begin{array}{l}0.90- \\
2.05\end{array}$ & 0.143 \\
\hline University degree & $94(74)$ & 2.16 & $1.42-3.30$ & $<0.001$ & 1.94 & $\begin{array}{l}1.21- \\
3.09\end{array}$ & 0.005 \\
\hline $\begin{array}{l}\text { Number of antibiotics } \\
\text { in the last year } \\
\begin{array}{c}1-3 \\
>3\end{array}\end{array}$ & $\begin{array}{l}51(40) \\
3(2.5)\end{array}$ & 2.53 & $1.83-3.49$ & $\begin{array}{l}<0.001 \text { (reference } \\
\text { to } 0 \text { antibiotic } \\
\text { usage in last year) }\end{array}$ & 0.45 & $\begin{array}{l}0.32- \\
0.64\end{array}$ & $<0.001$ \\
\hline $\begin{array}{l}\text { Informed by health } \\
\text { care provider }\end{array}$ & $58(45.6)$ & 1.70 & $1.17-2.48$ & 0.005 & 1.68 & $\begin{array}{l}1.11- \\
2.45\end{array}$ & 0.013 \\
\hline $\begin{array}{l}\text { Antibiotic use with } \\
\text { prescription only }\end{array}$ & $120(94.5)$ & 0.13 & $0.06-0.28$ & $<0.001$ & 0.15 & $\begin{array}{l}0.06- \\
0.33\end{array}$ & $<0.001$ \\
\hline
\end{tabular}

* Logistic regression (characteristics found to be significant in the univariate analysis included only)

within the last year. About $24 \%$ of the participants demand antibiotics when they visit a physician. Of these, 83.5\% have reported that the physicians complied with their demands. This underlines the pressure on physicians as a contributing factor for inappropriate antibiotic usage. In a similar study conducted in Ankara in 2014, Gül et al. reported that $64 \%$ of their participants demanded a prescription for antibiotics when they visited a physician (11). Recently, the Turkish Ministry of Health has launched a big campaign with the slogan "Don't insist on antibiotics, insist on your health." This slight decrease between 2017 and 2014 on demanding an antibiotic indicates an improvement and reveals the impact of this intervention. Educating people may improve JAU by alleviating this pressure.

JAU was found to be $12.2 \%$ while a similar study in Italy reported $21.2 \%$ (12). High income, education and cultural level were found to be related to JAU. These data are in parallel with studies from Malesia and Hong Kong $(13,14)$, which point out the importance of education.

While $27.6 \%$ of our participants have a history of using antibiotics without prescription, İlhan et al. reported a ratio of $19.1 \%$ in their study conducted in 2009 in Ankara (15). The rate of self-medication with antibiotics was reported as high as 64.3\% in another study conducted in 2014 in Ankara (11). This ratio was reported as $32.7 \%$ in Italy (12) and $7.6 \%$ in Malaysia (13). In 2016, the Turkish Ministry of Health banned the sale of antibiotics without a prescription. This precaution is expected to decrease antibiotic usage, and as such, the spread of resistance.

While our study did not find a correlation between gender and JAU ( $p=0.469)$, a study from Sweden reported that males used antibiotics more rationally compared to females (16), whereas the opposite was found in a study in Norway (17). 
Six hundred eighty-four (67.5\%) of our participants were aware of the term of antibiotic resistance. 117 (17.1.\%) of these could not link antibiotic use and the development of resistance. In Italy, 9.8\% could correctly define antibiotic resistance (12). In the study from Norway, $71 \%$ of participants were highly aware of antibiotic resistance (17). In the Malaysian study, 59\% of the participants knew the causes of antibiotic resistance (13). In a study from England, $97 \%$ of participants knew that antibiotics should not be used unnecessarily, and 79\% had an awareness of the rising rates of resistance in hospitals (18).

In our study, the primary source from where the participants heard the term antibiotic resistance was the internet ( $n=348,51.03 \%)$. In the study from Italy, the physicians (80.1\%) were the most important source (12). Our study showed that the patients who were informed about the possible harms of antibiotic use (34.9\%) had a high JAU. Thus, thorough information provided by the physicians may contribute to improving JAU.

Our study showed that $64.3 \%$ of the people keep unused antibiotics, and about 10\% offer leftover anti- biotics to others. In the study of Derin et al., it was determined that keeping antibiotics for future use was associated with inappropriate antibiotic use (9). In the same study, the rates of prematurely stopping antibiotics were found higher in those patients who used antibiotics for upper respiratory complaints. In our study, it was seen that 203 (19.4\%) of participants stopped taking antibiotics when their complaints subsided, and not completed the prescribed regimen. In order to prevent this inappropriate practice which may lead to antibiotic resistance, the number of pills can be limited by the duration of treatment in addition to informing the patients about the adverse effects of using leftover drugs.

Conclusion: The level of JAU is low in Ankara. This result was the consequence of not only the inadequate information provided by the health care professionals but also the low level of education and cultural status of the public. Informing people about the interaction between inappropriate antibiotic use and antibiotic resistance is pivotal in raising awareness as well as the level of JAU. Due to the wide distribution and ease of access, this information may be provided by health care professionals on web-based platforms.
Ethics Committee Approval: The Ethical Committee of Ankara University, Turkey, approved the study with the decision number of $23.12 .2016 / 7484$.

Informed Consent: Written consent was obtained from the patients.

Peer-review: Externally peer-reviewed

Author Contributions: Concept - T.O.A., M.B., E.E., D.D.K., I.N., M.Y., A.A.; Design - T.O.A., M.B., E.E., D.D.K., İ.N., M.Y., A.A.; Supervision
- D.D.K., A.A.; Data Collection and/or Processing - T.O.A., M.B., E.E., D.D.K., İ.N., M.Y.; Analysis and/or Interpretation - T.O.A., M.B., E.E., D.D.K., İ.N., M.Y., A.A.; Literature Review - T.O.A., M.B., E.E., D.D.K., İ.N., M.Y., A.A.; Writer - T.O.A., M.B., E.E., D.D.K., İ.N., M.Y., A.A.; Critical Reviews - T.O.A., M.B., E.E., D.D.K., İ.N., M.Y., A.A.

Conflict of Interest: The authors have no conflict of interest to declare.

Financial Disclosure: The authors declared that this study has received no financial support.

\section{REFERENCES}

1 World Health Organization (WHO). WHO global strategy for containment of antimicrobial resistance. WHO/CDS/CSR/DRS/2001.2. Available from: URL: https://www.who.int/drugresistance/WHO Global Strategy English.pdf (accessed on 20 Sep 2019)

2 European Centre for Disease Prevention and Control. Surveillance of antimicrobial resistance in Europe - Annual report of the European Antimicrobial Resistance Surveillance Network
(EARS-Net) 2017. Stockholm: ECDC; 2018

3 Review on Antimicrobial Resistance. Antimicrobial resistance: tackling a crisis for the health and wealth of nations. 2014. Available from: URL: https://amr-review.org/sites/default/files/ AMR\%20Review\%20Paper\%20-\%20Tackling\%20a\%20crisis\%20 for $\% 20$ the $\% 20$ health $\% 20$ and $\% 20$ wealth $\% 20$ of $\% 20$ nations 1. pdf. (accessed on 20 Sep 2019) 
4 Davey P, Pagliari C, Hayes A. The patient's role in the spread and control of bacterial resistance to antibiotics. Clin Microbiol Infect 2002;8:43-68.

5 Gualano MR, Gili R, Scaioli G, Bert F, Siliquini R. General population's knowledge and attitudes about antibiotics: a systematic review and meta-analysis. Pharmacoepidemiol Drug Saf 2015; 24: 2-10.

6 Lee CR, Cho IH, Jeong BC, Lee SH. Strategies to minimize antibiotic resistance. Int J Environ Res Public Health 2013; 10 . 4274-4305.

7 World Health Organization (WHO). WHO report on surveillance of antibiotic consumption, 2016-2018 early implementation. ISBN 978-92-4-151488-0. Available from: URL: https:// www.who.int/medicines/areas/rational_use/oms-amr-amcreport-2016-2018/en/ (accessed on 20 Sep 2019)

8 OECD Health Policy Studies. Stemming the superbug tide: just a few dollars more. Paris: OECD Publishing. Available from: URL: https://doi.org/10.1787/9789264307599-en (accessed on 25 Sep 2019)

9 Derin O, Ozdemir H, Sari M, Gulten E. Non-compliant antibiotic use in Dursunbey county: a cross-sectional study. Klimik Journal 2016; 29:125-129.

10 World Health Organization (WHO). The Pursuit of Responsible Use of Medicines: Sharing and Learning from Country Experiences. 2012. Available from: URL: https://www.who.int/medicines/areas/rational_use/en/ (accessed on 25 Sep 2019)

11 Gül, S., Öztürk, D. B., Yllmaz, M.S., Esen Uz, G. Evaluation of public knowledge and attitudes regarding self medication with antibiotics in Ankara. Turk Hij Deney Biyol Derg 2014; 71: 107-112. doi: 10.5505/TurkHijyen.2014.60024.
12 Napolitano F, Izzo MT, Di Giuseppe G, Angelillo IF. Public Knowledge, attitudes, and experience regarding the use of antibiotics in Italy. PLoS ONE 2013; 8: e84177 doi: 10.1371/journal. pone.0084177

13 Ling Oh A, Hassali MA, Al-Haddad MS, Syed Sulaiman SA, Shafie AA, Awaisu A. Public knowledge and attitudes towards antibiotic usage: a cross-sectional study among the general public in the state of Penang, Malaysia. J Infect Dev Ctries 2010; 5 : 338-347. doi: 10.3855/jidc.1502

14 You JH, Yau B, Choi KC, Chau CTS, Huang QR, Lee SS. Public knowledge, attitudes and behavior on antibiotic use: a telephone survey in Hong Kong. Infection 2008; 36: 153-157. doi: 10.1007/s15010-007-7214-5

15 Ilhan MN, Aydemir Ö, Çakır M, Aycan S. Akılcı olmayan ilaç kullanım davranışlan: Ankara'da üç ilçe örneği. Turk J Public Health 2014; 12: 188. doi: 10.20518/thsd.91650

16 Vallin M, Polyzoi ., Marrone G, Rosales-Klintz S, Wisell KT, Lundborg CS. Knowledge and Attitudes towards Antibiotic Use and Resistance - A Latent Class Analysis of a Swedish Population-Based Sample. Plos One, 2016;11(4): e0152160 doi: 10.1371/journal.pone.0152160

17 Waaseth M, Adan A, Røen IL, Eriksen K, Stanojevic T, Halvorsen $\mathrm{KH}$, et al. Knowledge of antibiotics and antibiotic resistance among Norwegian pharmacy customers - a cross-sectional study. BMC Public Health, 2019;19(1):66. doi: 10.1186/s12889019-6409-X

18 McNulty C, Boyle P, Nichols T, Clappison P, Davey, P. Dont wear me out - the publics knowledge of and attitudes to antibiotic use. J Antimicrob Chemother 2007;59:727-38. 


\section{SUPLEMENT: EVALUATION OF ANTIBIOTIC USAGE IN ANKARA}

Dear participant, this survey is prepared for a scientific study to figure out Judicious Antibiotic Usage (JAU) and its determinants. You won't be asked any questions that reveal your identity. Your answers will be used for scientific purposes only and the data collected in this study will be published as an article in scientific journals.

1. Your age:

2. Your occupation:

3. Your educational level:
a. Illiterate
b. Literate
c. Primary schoo
d. High school
e. University

4. Your sex:
a. Male
b. Female

5. Your monthly income (Turkish Lira):
a. $<1300$
b. $1300-5000 \mathrm{e}$
c. $3000-5000$
d. $>5000$

6. Number of households:

7. Number of books you read each year:

8. Do you read daily newspaper?
a. Yes
b. No

9. Is there any member in your family who takes medicines for a chronic illness?
a. Yes
b. No

10. How many courses of antibiotic did you use in the last 12 months?
a. 0
b. 1-3
c. $>3$

11. Have you ever used antibiotics without a prescription?
a. Yes
b. No

12. Have you ever participated in an educational programme about antibiotics? (i.e. taking a lecture, attending a conference etc.)
a. Yes
b. No

13. Have you been informed by your physician about the side effects of antibiotics?
a. Yes
b. No 
14. What do you do with the leftover antibiotics? (please select all that apply)
a. I keep them for future use
b. I throw them away
c. I return them to pharmacy
d. I offer them to acquaintances

15. What do you do when you miss taking your antibiotic on time?
a. I take it with the next dose
b. I take it as soon as I remember

16. For how long do you take prescribed antibiotics?
a. I take them as prescribed by my physician
b. I stop taking when I feel good

17. Do you think that antibiotics may have some harmful effects?
a. Yes, they may
b. No, they are safe

18. What kind of harmful effects do you think that antibiotics have?

19. Who may get affected by the harmful effects of antibiotics?
a. Only the one who uses antibiotics
b. The one who uses and his/her households
c. Entire society

20. Do you use leftover antibiotics?
a. Yes
b. No

21. Do you use antibiotics without prescription?
a. Yes
b. No

22. Do you use antibiotics when you have fever?
a. Yes
b. No

23. Do you use antibiotics when you have sore-throat?
a. Yes
b. No

24. Do you use antibiotics when you have runny nose?
a. Yes
b. No

25. Do you use antibiotics for the same complaints you had before and had been treated with antibiotics by a physician?
a. Yes
b. No 
26. Do you use antibiotics through advise of your acquaintances?
a. Yes
b. No

27. Do you recommend antibiotics to your acquaintances?
a. Yes
b. No

28. Have you ever asked your physician to prescribe an antibiotic?
a. Yes
b. No

29. Did your physician prescribe an antibiotic on your demand?
a. Yes
b. No

30. Have you ever heard about the term "antibiotic resistance" before?
a. Yes
b. No

31. (If you heard) From which source have you heard about antibiotic resistance? (pleaseselect all that apply)
a. TV
b. Newspapers
c. Social media
d. Internet
e. Friends
f. Educational programme (at school, conference, course etc.)

32. Do you think that taking antibiotic can cause "antibiotic resistance"?
a. Yes
b. No
c. I have no idea

33. Do you think that antibiotics can become ineffective in treating infections if they are used often?
a. Yes
b. No
c. I have no idea

Thank you very much four your help. 